\title{
Tradisi Ruwatan Jawa Pada Masyarakat Desa Pulungdowo Malang
}

\author{
Jijah Tri Suanti a,1*, Dinna Eka Graha Lestari b,2* \\ ab IKIP Budi Utomo Malang, Jalan Cintadui No. 46 Malang, 65122, Indonesia \\ ${ }^{1}$ jijahtrisusanti.pssbu@gmail.com;2 dynna_lestari@yahoo.com \\ * Corresponding Author
}

\begin{tabular}{l}
\hline INFO ARTIKEL \\
Sejarah Artikel: \\
Diterima: 9 \\
November2020 \\
Direvisi: 9 November \\
2020 \\
Disetujui: 12 November \\
2020 \\
Tersedia Daring: 16 \\
November 2020
\end{tabular}

Kata Kunci:

Budaya

Masyarakat

Ruwatan

Tradisi

\begin{abstract}
ABSTRAK
Jawa yang merupakan salah satu suku terbesar di Indonesia juga memiliki keanekaragaman budaya. Masyarakat Jawa kental dengan kepercayaan mistis atau sering disebut juga kepercayaan dalam dunia Spiritual. Masyarakat Jawa memiliki beragam teori yang menjadi dasar dilakukannya sebuah ritual. Upacara atau ritual yang dilakukan untuk menghindarkan diri dari dampak yang ditimbulkan akibat kesalahan manusia, dalam masyarakat Jawa disebut ruwatan. Tujuan penelitian ini adalah untuk mengetahui sejarah asal mula tradisi ruwatan adat Jawa bagi anak perempuan tunggal, mengetahui makna yang terkandung dalam tradisi ruwatan adat Jawa bagi anak perempuan tunggal, dan proses tradisi ruwatan adat Jawa bagi anak perempuan tunggal sebelum melakukan pernikahan. Metode penelitian ini adalah deskriptif kualitatif. Penelitian dilakukan di Desa Pulungdowo Kabupaten Malang. Sumber data penelitian ini adalah informan dan fenomena tradisi ruwatan. Teknik pengumpulan data dilakukan dengan observasi, wawancara dan studi dokumen. Teknik analisa data dilakukan dengan reduksi, interpetasi, dan penarikan kesimpulan. Hasil penelitian ini menunjukkan bahwa asal muasal adanya Ruwatan adalah dari cerita pewayangan ada seorang tokoh yang bernama Batara Guru dia beristrikan dua orang istri yaitu Pademi dan Selir. Ruwatan dilakukan dengan menggelar pertunjukan wayang lakon Murwakala. Dalang akan menyajikan sesaji khusus untuk memuja batarakala. Pada acara pamungkas dalang membaca mantra dengan iringan gamelan dan gending sebagai tolak bala (mengusir Batarakala). Makna dari ruwatan adalah meminta dengan sepenuh hati agar pelakunya lepas dari petaka dan memperoleh rahayu keselamatan. Hal tersebut memperlihatkan masih kuatnya kepercayaan masyarakat terhadap mitos dan tradisi utamanya bagi ruwatan anak perempuan tunggal sebelum melangsungkan pernikahan.
\end{abstract}

\begin{tabular}{ll}
\hline ABSTRACT \\
$\begin{array}{l}\text { Kulture } \\
\text { Society } \\
\text { Ruwatan } \\
\text { Tradition }\end{array}$ & asversity. Javanese society is thick with mystical beliefs or often referred to \\
as beliefs in the spiritual world. Javanese society has various theories on \\
which to conduct rituals. Ceremonies or rituals that are carried out to avoid \\
the impacts caused by human error, in Javanese society it is called ruwatan. \\
The purpose of this study is to determine the history of the origin of the \\
Javanese traditional ruwatan tradition for single girls, to know the meaning \\
contained in the Javanese traditional ruwatan tradition for single girls, and \\
the process of the Javanese traditional ruwatan tradition for single girls \\
before marriage. This research method is descriptive qualitative. The \\
research was conducted in Pulungdowo Village, Malang Regency. The data \\
sources of this research are informants and the traditional phenomenon of \\
ruwatan. The data collection technique was done by observing, interviewing \\
and studying documents. The data analysis technique is done by reducing, \\
interpreting, and drawing conclusions. The results of this study indicate that \\
the origin of Ruwatan is from the puppet story of a character named Batara
\end{tabular}


Guru who has two wives, namely Pademi and Selir. Ruwatan is carried out by holding a puppet show in the Murwakala play. The puppeteer will make special offerings to worship the batarakala. At the final event, the puppeteer recites mantras with gamelan accompaniment and gending as a repulsion (expelling Batarakala). The meaning of ruwatan is asking wholeheartedly for the perpetrator to escape from calamity and obtain the grace of salvation. This shows that the community's belief in the myths and traditions, especially for ruwatan single girls, is still strong before getting married.

\section{Pendahuluan}

Manusia memiliki berbagai macam kebutuhan, seperti kebutuhan biologis, kebutuhan psikologis, kebutuhan sosial, serta kebutuhan akan keamanan. Oleh karena itu, antara manusia yang satu dengan manusia yang lainnya saling memerlukan dan menggantungkan diri satu sama lain sehingga menimbulkan kelompok yang selalu berhubungan. Sebagai makhluk yang berbudaya dengan kebutuhan biologisnya manusia mengenal adanya perkawinan. Melalui perkawinan ini, seorang akan mengalami perubahan status sosialnya. Perubahan itu dari status bujangan ke status berkeluarga dan diperlukan sebagai anggota yang bertanggung jawab serta bermanfaat bagi kehidupan bermasyarakat. Bagi suku bangsa yang memiliki adat budaya, perkawinan merupakan suatu hal yang sangat penting dalam daur kehidupan dan dilaksanakannya dalam suatu upacara yang terhormat serta mengandung unsur sakral di dalamnya (Hariwijaya, 2005). Upacara merupakan "sistem aktifasi atau rangkaian tindakan yang ditata oleh adat atau hukum yang berlaku dalam masyarakat yang berhubungan dengan berbagai macam peristiwa tetap, yang biasanya terjadi dalam masyarakat yang bersangkutan" (Suyono, 1985:423). Berdasarkan hal inilah upacara menjadi suatu hal yang cukup penting dan menjadikan individu merasa dirinya terangkat statusnya dalam kehidupan sosial. Demikian juga kelompok etnis Jawa. Suku
Jawa juga mempunyai cara dan adat istiadat dalam mengatur acara perkawinan. Upacara perkawinan dianggap sesuatu yang sangat sakral yang terjadi dalam kehidupan masyarakat. Karena kesakralan dan kewajiban yang hanya terjadi sekali seumur hidup serta menjadi tanggung jawab terakhir orang tua terhad ap anaknya, perkawinan adat suku Jawa dilakukan secara meriah serta melalui berbagai prosesi yang sakral. Perkawinan adat Jawa di Kecamatan Tumpang, Kabupaten Malang terdiri dari beberapa tahapan yaitu dimulai dari (melamar dari pihak pria kepada pihak wanita), (memutuskan) diterima atau tidaknya lamaran pihak pria. Bila diterima maka akan langsung membicarakan hal -hal apa saja yang harus diperlukan atau berapa jumlah barang dan uang yang dibutuhkan keluarga pihak wanita guna melangsungkan upacara perkawinan. Kemudian mengantarkan barang-barang yang telah disepakati oleh kedua belah pihak, dari calon mempelai pria ke calon mempelai wanita, barodaq (luluran di masing masing kediaman calon pengantin), akad nikah (biasanya dilakukan di kediaman pengantin wanita pengantin ini diarak keliling desa dan dilakukan sebelum acara resepsi perkawinan dilakukan), dan tahap yang terakhir adalah basai (resepsi perkawinan).

Ruwatan merupakan tradisi perkawinan adat Jawa yang memiliki keunikan sendiri atau berbeda dengan tradisi-tradisi perkawinan di daerah lainnya. Peneliti 
merasa prihatin terhadap ketidakpedulian generasi muda Jawa terhadap tradisi-tradisi leluhur mereka, sehingga diharapkan dengan adanya penelitian seperti ini generasi muda tergugah untuk melestarikan kebudayaan daerahnya yang telah diwarisi secara turun temurun oleh nenek moyangnya.

Penelitian ini bertujuan mendeskripsikan sejarah asal mula tradisi ruwatan adat Jawa bagi anak perempuan tunggal, proses ritual dilakukan, dan makna yang terkadung dalam tradisi ruwatan yang dilakukan.

Beberapa penelitian yang relevan dengan penelitian ini sebagai berikut. Penelitian yang dilakukan oleh Noraini (2016), meneliti tradisi ruwat bagi anak "Ontang-Anting" di Dusun Tangkil, Kelurahan Muntuk, Kecamatan Dlingo, Kabupaten Bantul (Perspektif Hukum Adat dan Hukum Islam). Tradisi Ruwatan di Dusun Tangkil ini dilakukan sebelum upacara perkawinan bagi "ontang-anting" anak tunggal baik laki-laki ataupun perempuan. Upacara ruwatan dianggap sebagai wahana pembebasan para sukerta (anak yang dianggap membawa sial atau anak yang diyakini bahwa jiwanya bisa dimakan oleh Batara Kala).Oleh sebab itu, dilaksanakanlah upacara ruwatan yang bertujuan untuk membabaskan dari malapetaka atau kesialan dalam hidupnya. Upacara ruwatan di Dusun Tangkil ini biasanya dilaksanakan pada malam hari. Pelaksanaan ruwatan ini dimulai dengan menyiapkan segala sesuatu yang menjadi syarat dan sesaji dalam prosesi pengruwatan. Syarat-syarat ruwatan, seperti gagar mayang yang meliputi; Pegaron (tempat air yang terbuat dari tanah liat) dan siwur (gayung terbuat dari tempurung kelapa), air yang dicampur dengan bunga Telon (tiga macam bunga), melakukan do'a yang dipimpin oleh tokoh adat, dan dilanjutkan dengan cukur rambut kemudian memandikan seseorang yang akan diruwat dengan menggunakan tujuh mata air. Pada pelaksanaan pengruwatan ini anak sukerta akan dimandikan oleh salah satu tokoh adat masyarakat sekitar. Penyediaan sesaji dalam ritual ini, seperti telur, sepasang ayam kampung, abon-abon (daun sirih, kemenyan, tembakau dan uang) sebagai wujud rasa terima kasih kepada Gusti Sang Maha Pencipta. Setelah itu semua yang digunakan dalam prosesi ruwatan akan dibuang ke sungai. Kesialan yang dimiliki oleh anak sukerta ini dianggap telah hilang ikut terbuang seiring dengan dengan pelarungan barang-barang tersebut. Oleh karena itu, tradisi ruwatan ini masih dilakukan dan dipercayai sebagai salah satu syarat sebelum melakukan pernikahan bagi setiap anak tunggal di Dusun Tangkil tersebut.

Penelitian selanjutnya dilakukan Ulya Zulfa (2009) dengan judul "Tinjauan Hukum Islam Terhadap Adat Ruwatan Perkawinan Anak Tunggal Di Desa Purworejo Kecamatan Bonang Kabupaten Demak". Adapun penelitian yang dilakukan memperlihatkan bahwa menurut kepercayaan, acara ruwatan mempunyai maksud membersihkan diri dari malapetaka yang disebabkan oleh pembalasan Batara Kala terhadap sukerta (orang yang memenuhi penggolongan tertentu), misalnya orang ontang-anting, uger-uger lawang, kedhana-kedhini. Dalam masyarakat Jawa tatanan suatu budaya yang membentuk kepercayaan bahwa manusia yang dilahirkan membawa takdirnya sendiri-sendiri namun takdir ini masih bisa diusahakan untuk dihindarkan, yaitu takdir yang berupa malapetaka disebabkan oleh tiga hal, yaitu 1) kodrat yang dibawa sejak manusia dilahirkan, 2) perbuatan atau kesalahan baik sengaja maupun yang tidak disadari, 3) karena mendapatkan rintangan (halangan) dalam hidup dan atau melangar suatu pantangan. Orang yang termasuk dalam tiga hal tersebut dinamakan nandhang sukerta yang hanya dapat dibersihkan atau disucikan melalui suatu upacara ritual yang disebut ruwatan. Cerita tentang terjadinya upacara ruwatan dimulai dari kepercayaan tentang datangnya malapetaka yang akan menimpa anak sukerta dan orang-orang yang bernasib sial lainnya berasal dari keyakinan akan sebuah cerita lama, yaitu dari sebuah cerita wayang purwa yang disebut murwakala atau purwakala. Purwa berarti asal atau 
permulaan. Kala berati bencana. Jadi asal mula dari bencana. Jalan upacara ruwat dengan pementasan wayang. Pada umumnya orang mengadakan ruwatan kurang mengetahui sendiri akan seluk beluk upacara itu. Sebagai orang awam mereka tidak begitu paham barang-barang apakah atau syaratsyarat apakah yang harus disediakan. Acara ruwatan dimulai dengan acara memandikan anak yang akan diruwatnya, pada pagi hari kira-kira jam 09:00 yang harus ditangani sendiri ibu dari anak yang bersangkutan. Air yang digunakan adalah air setaman atau air yang ditaburi bunga-bunga yang harum. Selesai dimandikan anak diberi pakaian yang indah, kemudian dengan diantar oleh dalang dan neneknya dihadapkan kepada orang tuanya untuk bersujud. Selanjutnya upacara diteruskan dengan mengadakan selametan dan doa yang dilakukan oleh dalang dan yang dihadiri oleh keluarga dan kerabat tuan rumah. Anak beserta orang tua dan neneknya dipersilahkan duduk di dekat dalang. Demikian pula sajiannya, diletakkan di atas meja yang telah disediakan. Sebelum gamelan mulai dipukul, dalang menyerahkan lima potong batang tebu wulung, 21 kuntum kembang melati dan sebuah tunas kelapa (cikal) kepada keluarga anak dan sebagai gantinya akan diminta baju dalam diri anak yang bersangkutan. Malam pembacaan terakhir merupakan acara puncak dari upacara, pada malam itu diadakan sedekah dan sajian yang disediakan antara lain 1) air setaman di dalam belanga, 2) pisang raja setangkap (dua sisir), 3) sekul wuduk (nasi gurih), 4) ingkung ayam (daging ayang yang telah dimasak), 5) jajan pasar (macammacam kue yang dibeli dari pasar), 6) sekul golong (nasi yang dibentuk setengah bulatan), 7) sekul tumpeng (nasi yang dibentuk seperti kerucut), 8) lauk pauk gudangan (macam-macam sayur yang direbus diberi ramuan sambal kelapa), 9) rujak-rujakan (macam-macam buah, seperti mangga muda, mentimun, nanas yang dipotong-potong dimakan dengan sambal), 10) kue apem yang terbuat dari tepung beras, kolak adalah makanan yang dibuat dari irisan pisang dan ketela dimasak dengan santan dan gula. Setelah selesai sedekahan, upacara dilanjutkan dengan pengguntingan rambut dan pemandian anak yang di ruwat. Dalam upacara mandi, anak disiram bergabti-ganti oleh orang-orang kerabat keluarga yang dianggap tua.

Ketiga, penelitian yang dilakukan Luluatul Fuadah (2018) dengan judul "Tradisi Ruwatan Dalam Acara Pranikah Bagi Anak "Ontang-Anting" Perspektif Hukum Islam (Studi Kasus Di Desa Ampelsari Kecamatan Petanahan Kabupaten Kebumen)". Adapun penelitian yang dilakukan pada praktik dari tradisi ruwatan dalam acara pranikah bagi anak ontanganting di desa Ampelsari. Pada umumnya, dalam acara pra-nikah diawali dengan pengajian pra-nikah, lalu dilanjutkan malmnya dengan malam midodareni. Namun, di Desa Ampelsari, dalam acara pranikah ada yang namanya ritual sebelum melaksanakan perkawinan, namun dikhususkan hanya untuk anak tertentu seperti anak ontang-anting (anak tunggal atau hanya satu yaitu laki-laki maupun perempuan), yang dipercayai apabila tidak melaksanakan prosesi ruwatan tersebut maka anak yang bersangkutan akan mendapat bahaya atau malapetaka. Sehingga sebagai orang tua di masyarakat Desa Ampelsari yang mempunyai anak tunggal (ontanganting), sebelum melangsungkan pernikahan maka mengadakan tradisi pra-nikah yaitu tradisi ruwatan. Penelitian tersebut menyimpulkan bahwa ruwatan yaitu upacara yang dilakukan untuk menghilangkan dampak berbentuk kesialan, menjauhkan segala kemungkinan yang buruk yang bias terjadi, dengan cara-cara tertentu dengan tujuan yang beragam. Ruwatan yang dimaksud dalam penelitian yaitu ruwatan yang dilaksanakan di desa tersebut bahwa setiap anak tunggal (ontang-anting) yang akan menikah maka dilaksanakan Ruwatan terlebih dahulu. Tradisi ruwatan dalam pernikahan yang berkembang di Desa Ampelsari dalam praktiknya melihat uraian makna benda-benda dan prakteknya tidak melibatkan unsur yang bertentangan dengan hokum Islam, karena tradisi ini didasari 
dengan rasa lillahita'ala hanya untuk mencari keridha'an Allah SWT.

Berdasarkan hal tersebut, penelitian ini belum pernah dilakukan sebelumnya. Penelitian ini perlu dilakukan karena jika dibiarkan akan punah atau banyak generasi muda yang tidak akan mengenal lagi tradisi ini atau keberadaannya saat ini terabaikan dalam masyarakat. Menurut Koenjaraningrat (1985), tradisi merupakan keyakinan nenek moyang terdahulu yang dikenal dengan istilah animisme dan dinamisme. Animisme berarti percaya kepada roh-roh halus atau roh leluhur yang ritualnya dalam persembahan tertentu di tempat-tempat yang dianggap keramat. Semua yang bergerak dianggap hidup dan mempunyai kekuatan gaib atau memiliki roh yang berwatak baik maupun buruk. Kepercayaan nenek moyang yang masih beranggapan bahwa di samping semua roh yang ada, terdapat roh yang paling berkuasa yang lebih kuat dari manusia. Supaya terhindar dari roh tersebut mereka menyembahnya dengan jalan upacara yang disertai dengan sesaji-sesaji. Dinamisme adalah suatu istilah untuk menyebut sesuatu pengertian tentang kepercayaan. Kata dinamisme berasal dari kata Yunani "dynamis" atau "dynaomos" yang berarti kekuatan atau tenaga. Jadi dinamisme ialah kepercayaan bahwa benda-benda tertentu memiliki kekuatan gaib, karena itu harus dihormati dan terkadang harus dilakukan ritual tertentu untuk menjaga tuahnya. Keyakinan semacam itu membentuk perilaku dalam kehidupan sehari-hari, baik dalam wujud etika maupun ekspresi dalam berkesenian.

Tradisi merupakan suatu kebiasaan yang turun-temurun dalam suatu masyarakat, dan merupakan mekanisme yang dapat membantu untuk memperlancar perkembangan pribadi anggota masyarakat. Misalnya dalam membimbing anak menuju kedewasaan. Tradisi ini juga penting sebagai pembimbing pergaulan bersama dalam masyarakat. Tradisi yang diterima perlu direnungkan dan disesuaikan dengan zamannya. Menurut Adeney (2000:159), tradisi merupakan salah satu fenomena kebudayaan karena tradisi adalah praktik kebudayaan dari suatu komunitas. Praktik kebudayaan memperlihatkan makna dari nilai kebudayaan, di mana nilai-nilai kebudayaan merupakan tujuan dari manusia untuk memenuhi kebutuhan dasarnya. Menurut Soetarto (1980:77), tradisi merupakan suatu tindakan yang berulangulang kali terjadi dilakukan dan diwariskan secara turun-temurun. Salah satu tradisi adalah ruwatan sebagai salah satu warisan tradisional Jawa sampai sekarang masih dilestarikan. Ruwatan adalah masalah penyucian dalam mengatasi atau menghindarkan sesuatu kesulitan batin dengan dengan jalan mengadakan pertunjukan wayang kulit dengan mengambil cerita tertentu dalam pewayangan. Tradisi adalah segala warisan masa lampau yang masuk pada kita dan masuk kedalam kebudayaan yang sekarang berlaku. Dengan demikian, bagi Hanafi tidak hanya persoalan tentang peningalan sejarah, tetapi sekaligus merupakan persoalan kontribusi zaman kini dalam berbagai tingkatannya.

Tradisi berarti segala sesuatu seperti adat, kebiasaan, ajaran, dan sebagainya, yang turun-temurun dari nenek moyang. Adapula yang menginformasikan, bahwa tradisi berarti berasal dari kata traditium, yaitu segala sesuatu yang di transmisikan, diwariskan oleh masa lalu ke masa sekarang. Berdasarkan dua sumber tersebut dapat dipahami bahwa tradisi adalah warisan masa lalu yang dilestarikan, dijalankan, dan dipercaya hingga saat ini. Tradisi atau adat tersebut dapat berupa nilai, norma sosial, pola kelakuan dan adat kebiasaan lain yang merupakan wujud dari berbagai aspek kehidupan.

Adat dapat dikatakan sebagai tradisi lokal (local custom) yang mengatur interaksi masyarakat. Dalam ensiklopedia (Melalatoa, 1995), disebutkan bahwa adat adalah kebiasaan atau tradisi masyarakat yang telah dilakukan berulang kali secara turuntemurun. Kata "adat" lazim dipakai tanpa membedakan mana yang mempunyai sanksi seperti "hukum adat" dan mana yang tidak mempunyai sanksi seperti disebut adat saja. 
Secara tertimologi perkataan tradisi mengandung suatu pengertian tersembunyi tentang adanya kaitan antara masa lalu dan masa kini. Tradisi memperlihatkan bagaimana anggota masyarakat bertingkah laku, baik dalam kehidupan yang bersifat duniawi maupun terhadap hal-hal yang bersifat gaib atau keagamaan. Dalam tradisi diatur bagaimana manusia berhubungan dengan manusia yang lain, bagaimana perilaku manusia terhadap bertindak terhadap lingkungannya, dan bagaimana perilaku manusia terhadap alam yang lain. Tradisi berkembang menjadi suatu sistem, memiliki pola dan norma yang sekaligus juga mengatur penggunaan sanksi dan ancaman terhadap pelangaran dan penyimpangan.

\section{Metode}

Pendekatan yang digunakan dalam penelitian ini adalah kualitatif. Menurut Kirk dan Miller (dalam Moleong, 2002:3), penelitian kualitatif secara fundamental bergantung pada pengamatan manusia dalam kawasannya sendiri dan hubungan dengan orang-orang tersebut dalam bahasanya dan peristilahannya. Penelitian ini menggunakan pendekatan kualitatif karena menyajikan secara langsung hakikat hubungan antara peneliti dan informan. Penelitian ini juga lebih peka dan dapat menyesuaikan diri dengan banyak pengaruh bersama terhadap pola pola nilai yang dihadapi. Penelitian kualitatif disebut juga dengan penelitian naturalistik (Nasution, 1992:18). Disebut kualitatif karena sifat data yang dikumpulkan bercorak kualitatif, bukan kuantitatif karena tidak menggunakan alat alat pengukur. Disebut naturalistik karena situasi lapangan penelitian bersifat wajar atau natural, sebagai adanya tanpa dimanipulasi, diatur dengan eksperimen atau tes. Dalam Penelitian ini digunakan data deskriptif yang banyak dituangkan dalam bentuk laporan dan uraian. Peneliti mengumpulkan data berdasarkan observasi situasi yang wajar atau sebagaimana adanya, tanpa dipengaruhi dengan sengaja.

Penelitian dilakukan di Desa

Pulungdowo, Kecamatan Tumpang,
Kabupaten Malang. Sumber data penelitian adalah fenomena ruwatan, informan, dan dokumen. Informan dipilih menggunakan metode snow ball (Nasution, 1992:32). Peneliti sebelumnya bertanya kepada pihak kecamatan Tumpang tentang siapa yang bisa dihubungi berkaitan dengan tujuan penelitian. Wawancara dilakukan dengan tokoh adat, tokoh masyarakat setempat, serta orang orang yang dianggap tahu tentang tradisi ruwatan di Kecamatan Tumpang. Pengamatan dalam penelitian ini adalah pengamatan tanpa peran serta sebab pengamat hanya melakukan satu fungsi yaitu pengamatan (Moleong, 2002:126). Dalam penelitian ini kehadiran penelitian ini tidak diketahui oleh umum atau subjek yang diteliti, dalam hal ini pengamat menjadi salah satu tamu dalam upacara perkawinan yang dilaksanakan di kecamatan Tumpang Kabupaten Malang untuk mengetahui bagaimana upacara itu berlangsung, serta bagaimana pelaksanaan dari tradisi ruwatan. Peneliti memilih pengamatan peran serta dan tidak diketahui subjek penelitian dengan alasan takut kehadirannya dapat mempengaruhi orang orang yang diamati. Orang yang menjadi sasaran juga akan memperhatikan apa yang akan dilakukan peneliti yang akan mengamati mereka, bilamana mereka melihat peneliti, tak jarang mereka terpengaruh oleh kehadirannya sehingga mereka berbuat lain daripada bila peneliti tersebut tidak mengamati mereka. Perubahan yang terjadi akibat kehadiran peneliti tidak lagi merupakan keadaan yang murni, keadaan yang sesungguhnya hendak dipelajari oleh peneliti. Dalam penelitian ini pengamatan dilakukan untuk memperoleh data mengenai kondisi masyarakat Kecamatan Tumpang baik kondisi geografis, kondisi social, ekonomi, maupun budayanya serta mengamati secara langsung tradisi Ruwatan pada upacara perkawinan adat suku Jawa di Kecamatan Tumpang, kabupaten Malang.

Jenis wawancara yang dilakukan adalah wawancara tak berstruktur, artinya wawancara ini akan diajukan pertanyaan pertanyaan secara leluasa tanpa terikat 
dengan tujuan agar informan dan peneliti dapat berkomunikasi secara bebas serta informasi yang diperoleh lebih luas dan menyeluruh. Keadaan yang demikian ini memungkinkan diperoleh informasi yang lebih lengkap dan pembicaraan tidak terlampau terpaku pada akhirnya menjemukan kedua belah pihak. Penelitian ini juga menggunakan dokumen berupa arsip desa yang berhubungan dengan prosesi perkawinan adat suku Jawa di Kecamatan Tumpang Kabupaten Jawa.

Data yang terkumpul dianalisis dengan melakukan pengecekan data observasi lapangan dan disesuaikan data utama yakni hasil wawancara dengan informan. Kemudian data ini dikelompokkan dan diorganisasikan menurut jenis, kualitas, dan relevansi nya terhadap penelitian. Komponen analisis yang digunakan adalah reduksi data, sajian data, pemeriksaan kesimpulan. Ketiga komponen tersebut terlibat dalam suatu proses dan saling berkaitan, sehingga menentukan hasil akhir dari penelitian. Reduksi data dilakukan dengan cara mengkategorikan berdasarkan tema tema yang ada. Kemudian data disajikan secara sistematis berdasarkan yang telah dirumuskan. Tampilan data yang dihasilkan digunakan untuk interpretasi data. Kesimpulan ditarik setelah di adakan kroscek terhadap sumber lain melalui wawancara, dokumentasi, serta pengamatan.

\section{Hasil dan Pembahasan \\ 3.1 Asal Usul Ruwatan}

Asal usul adanya ruwatan adalah dari cerita pewayangan. Diceritakan ada seorang tokoh yang bernama Batara Guru beristrikan dua orang wanita, yaitu Pademi dan Selir. Dari istri Pademi dia menurunkan anak lakilaki bernama Wisnu. Setelah dewasa Wisnu menjadi orang yang berbudi pekerti yang baik, sementara dari istri Selir dia juga menurunkan seorang anak laki-laki yang bernama Batarakala. Setelah dewasa Batarakala menjadi orang yang jahat, konon katanya karena kesurupan setan. Dia sering menganggu Jalma atau anak manusia untuk dimakannya. Ruwatan ini semula berkembang di dalam suatu cerita Jawa yang padaintinya menurut masalah penyucian diri. Hal yang dimaksud dengan penyucian ini adalah menyangkut pembebasan diri dari kesialan atau marabahaya yang akan menimpanya. Batarakala lahir karena nafsu dari Batara Guru yang tidak terkendalikan. Diceritakan Batara Guru dan istrinya sedang bercengkerama mengelilingi samudera dengan menaiki punggung seekor lembu. Tiba-tiba hasrat seksual Batara Guru timbul dan dia ingin menyetubuhi istrinya di atas punggung lembu itu. Namun, istrinya menolak dan akhirnya jatuhlah sperma Batara Guru tersebut ke tengah samudera. Sperma ini kemudian menjelma menjadi raksasa yang dikenal dengan nama Batara Kala. Sperma yang jatuh tidak pada tempatnya ini dalam bahasa Jawa disebut sebagai kama salah. Jadi Batarakala ini merupakan perwujudan dari kama salah tersebut. Seperti yng disampaikan Bapak Madjono (86 tahun) pada saat wawancara dengan peneliti sebagai berikut.

\section{"Asal usul e ruwatan iku mbiyen soko leluhur e wong Jowo yen percoyo nang wong-wong seng ngowo apese urip mulane kudu diruwat ben ora dadi panganane Batarakala".}

Terjemahan

"Bahwa asal usul adanya ruwatan dahulu dari nenek moyang masyarakat Jawa yang percaya bahwa orang-orang yang membawa kesialan itu wajib diruwat agar tidak menjadi makanan Batarakala". (wawancara tanggal 22 Maret 2020)

Dalam ceritanya Batarakala meminta makanan yang berwujud manusia kepada Batara Guru. Batara Guru mengizinkan asal yang dimakannya itu adalah manusia yang digolongkan dalam kategori wong sukerta, yaitu orang-orang yang mendapat kesialan dalam hidupnya seperti anak tunggal yang tidak mempunyai saudara. Oleh karena itu anak tunggal (ontang-anting) harus diruwat agar terhindar dari malapetaka atau kesialan dalam hidupnya juga agar tidak menjadi 
makanan dari Batarakala. Oleh karena itu untuk menghilangkan kesialan atau marabahaya tersebut saat melaksanakan ruwatan harus melengkapi syarat-syarat yang diperlukan di antaranya adalah sajen. Sajen adalah untuk upacara ruwatan secara garis besar terdiri dari 1) tuwuhan, 2) ratus atau kemenyan wangi, 3) kain mori putih, 4) kain batik, 5) padi segedeng, 6) bermacam-macam nasi, 7) jenang, 8) jajan pasar, 9) benang lawe, 10) aneka rujak, 11) air tujuh sumber, dan 12) bunga setaman.

Dari cerita pewayangan inilah masyarakat Jawa meyakini bahwa tradisi ruwatan sangatlah penting bagi mereka yang mengharapkan keselamatan, khususnya bagi mereka yang hanya mempunyai satu anak. Agar anaknya selamat dan terhindar dari segala macam keburukan atau kesialan. Ruwatan yang diyakini oleh kebanyakan orang Jawa sebagai solusi agar jalma atau anak yang bersangkutan terhindar dari mara bahaya adalah suatu upacara yang acaranya sebagai berikut.

1) Mengadakan pagelaran wayang. Sebagai pemandu pagelaran wayang yaitu Dalang.

2) Lakon yang dipentaskan adalah lakon khusus yaitu lakon Murwakala.

3) Menyajikan sesaji khusus untuk memuja Batarakala.

4) Pada acara pamungkas ruwatan, Dalang membaca mantra-mantra dengan iringan gamelan dan gending tertentu guna untuk tolak balak (mengusir Batarakala).

Seperti yang disampaikan Bapak Madjono (86 tahun) pada saat wawancara dengan peneliti sebagai berikut:

\footnotetext{
"Lumrahe masyarakat niku nindakaken ruwatan enggeh meniko nanggep pgelaran wayang nganti tengah wengi (para isuk). Sakderengipun nindakaken pagelaran wayang kudu ngelakoni ritual siraman kembang setaman kangge ngilangaken kala. Sak sampunipun langsung ngelaksana'aken pagelaran wayang kaleh nyiapaken sajen-sajen seng dibutuhake".
}

\section{Terjemahan}

"Umumnya masyarakat itu melakukan ruwatan dengan mengadakan pertunjukan wayang sampai tengah malam (semalam suntuk). Sebelum melaksanakan pagelaran wayang terlebih dahulu melakukan ritual siraman bunga setaman unntuk menghilangkan kala (kesialan). Sesudah itu langsung melaksanakan pagelaran wayang dengan menyiapkan sajian-sajian yang dibutuhkan". (wawancara tanggal 22 Maret 2020)

Upacara ritual ruwatan adat Jawa ini sebenarnya sangat erat hubungannya dengan adanya sebuah kepercayaan yang sudah cukup lama dilestarikan di Pulau Jawa. Masyarakat tradisional Jawa sangat mempercayai bahwa kehidupan mereka itu sebenarnya sangat dipengaruhi oleh sang kala, dalam pewayangan diperankan oleh Batarakala. Kala yaitu sial atau pembawa malapetaka dalam kehidupan manusia, baik manusia secara individu maupun manusia secara berkelompok sosial.Dalam cerita Murwakala terdapat makna arti kehidupan yang sangat mendasar, arti penting ialah masyarakat Jawa sering mengaitkan antara peristiwa yang terjadi didalam dunia wayang dengan dunia nyata. Hakikat wayang adalah bayangan dunia nyata, yang di dalamnya terdapat makhluk ciptaan Tuhan. Dalam pewayangan visualisasi Batarakala adalah Dewa berwajah raksasa yang tinggi, besar, menyeramkan, dan menakutkan. Anggapananggapan ini lama-kelamaan menjadi keyakinan yang kokoh di dalam masyarakat Jawa. Agar terhindar dari ancaman Batarakala maka mereka harus mengadakan upacara ruwatan dengan sarana pertunjukan wayang dengan lakon Murwakala.

\subsection{Makna Tradisi Ruwatan Adat Jawa Bagi Anak Tunggal}

Makna dari ruwatan adalah meminta dengan sepenuh hati agar pelakunya lepas dari petaka dan memperoleh rahayu keselamatan. Tradisi ruwatan sampai sekarang masih dilakukan dan menjadi tradisi karena merasa belum nyaman kalau 
belum melaksanakan tradisi tersebut dan juga khawatir kalau terjadi hal-hal yang tidak diinginkan atau karena musibah yang bertubi-tubi menimpa walaupun secara sosial religius telah menjalankan semua syariat agamanya. Tradisi ruwatan anak tunggal hingga saat ini masih dilestarikan dan dilaksanakan secara turun-temurun oleh masyarakat setempat. Hal tersebut disebabkan oleh sebagian besar masyarakat masih menganggap bahwa tradisi ini merupakan kegiatan sakral. Kepercayaan akan tradisi ruwat anak tunggal yang berpengaruh pada keselamatan anak tunggal dan keluarganya. Selain itu dikarenakan alasan ingin melestarikan adat-istiadat yang sudah turun-temurun dilakukan oleh masyarakat Jawa, pada hakikatnya manusia hidup bermasyarakat oleh aturan dan tradisi dengan maksud tujuan teretntu. Aturan atau tradisi ini yang menjadi kebiasaan-kebiasaan uang mewujudkan adanya tradisi di dalam masyarakat.

Maksud dari tradisi ruwatan ini adalah agar seseorang yang di ruwat dapat terbebas atau terlepas dari malapetaka. Seseorang yang dianggap mempunyai kesialan disebut sebagai sukerta, artinya orang tersebut harus di ruwat. Tradisi kepercayaan masyarakat Jawa bahwa seseorang yang terkena sukerta akan mengalami kesialan di dalam hidupnya. Karena itu usaha yang dilakukan oleh masyarakat Jawa dengan mengadakan upacara ruwatan tersebut tak lain, yaitu untuk melindungi manusia dari segala ancaman bahaya dari kehidupannya di dunia. Tradisi ruwatan yang diselenggarakan oleh masyarakat Jawa tidak terlepas dengan gelaran wayang kulit yang mengangkat cerita lakon murwakala. Dalam sajiannya wayang murwakala dimaksudkan untuk mengusir roh jahat yang berada di dalam tubuh seseorang yang diruwat.

Ruwatan sangat bermakna bagi masyarakat kejawen. Kejawen merupakan kepercayaan asli Jawa atau kebatinan. Kebatinan merupakan sistem kepercayaan yang berakar pada kebudayaan. Kepercayaan yang memberikan dorongan orang yang melaksanakan ruwatan adalah bagi anak-anak yang mempunyai nasib buruk. Ruwatan ini dilakukan agar kehidupan anak tunggal tersebut tentram dan selamat dari marabahaya. Tradisi ruwatan mempunyai makna filosofis dalam tahapan prosesi upacaranya yaitu sebagai berikut.

a. Prosesi siraman secara filosofis mengandung nilai pembersih badan agar manusia yang di ruwat dengan menggunakan air kembang setaman yang terdiri atas kembang kenanga, kembang melati, dan kembang mawar.

b. Sesaji dan selametan secara filosofis memiliki nilai agar orang yang di ruwat dalam keadaan selalu selamat.

c. Nilai filosofis yang terkandung dalam upacara penyerahan sarana adalah memberikan perlindungan terhadap orang yang tergolong sukerta.

d. Upacara potong rambut memiliki nilai filosofis yaitu bahwa segala yang kotor harus di potong dan di buang.

e. Nilai filosofis dalam tirakatan merupakan ungkapan rasa syukur dan ungkapan rasa terima kasih terhadap Tuhan Yang Maha Esa atas perlindungan dan anugerahnya.

f. Wayang juga membawa makna filosofis bagi kehidupan manusia. Manusia pada umumnya menginginkan kebaikan, maka kisah wayang itu banyak yang bisa sampai masuk ke hati. Makna wayang dalam ruwatan juga membawa makna kehidupan.

Dalam ruwatan selain untuk membersihkan diri juga menghindarkan diri dari segala sesuatu yang tidak baik, bahwa setiap manusia sangatlah dianjurkan untuk menjalankan tujuh macam tapa, yaitu

a. Tapa jasad, yakni laku bad an jasmani. Hati agar dibersihkan dari sifat benci dan sakit hati, rela atas nasibnya, merasa dirinya lemah, tidak berdaya.

b. Tapa budi, yaitu laku batin. Hati harus jujur, menjauhi berbuat dusta, segala janji harus ditepati. 
c. Tapa hawa nafsu, yaitu berjiwa sabar serta suka memaafkan kesalahan orang lain.

d. Tapa brata atau tapa rasa jati, yaitu agar memaksa diri melakukan semedi, mencapai ketenangan hati.

e. Tapa sukma, yaitu bermurah hati.

f. Tapa cahaya yang memancarkan cahaya yaitu agar hati selalu awas dan ingat, mengerti lahir batin, selalu mengutamakan tindak yang mendatangkan keselamatan

g. Tapa hidup, yaitu hidup dengan penuh kehati-hatian dengan hati yang teguh, dengan hati percaya tidak khawatir terhadap apa yang akan terjadi.

Pelaksanaan ruwatan ini ada hubungannya dengan makna dari kesucian jiwa dan raga dalam kepercayaan masyarakat Jawa. Oleh karena itu sebelum pelaksanaan ruwatan harus melaksanakan tapa brata (ngelakone tapa). Kesucian jiwa raga adalah mencapai ketentraman dan kesucian lahir dan batin, selain itu juga mencapai kehidupan yang lebih baik dan suci lahir batin. Pelaksanaan ruwatan juga bermakna untuk mencapai tujuan hidup manusia Jawa tersimpul dalam unen-unen, mati sajroning urip, urip sajroning pejah, artinya bahwa yang hidup tetap hidup tetapi yang mati adalah nafsu lahirnya. Unen-unen mengandung pesan bahwa hidup manusia hendaknya bisa mengendalikan hawa nafsu. Orang yang tidak bisa menguasai nafsu berarti mati. Sebaliknya jika orang hidup tanpa nafsu adalah mati juga. Hidup manusia itu silih berganti seperti halnya perputaran roda, Okarena makna ruwatan sangatlah penting bagi kehidupan manusia yang tidak mempunyai saudara atau disebut sebagai anak tunggal (ontang-anting).

\subsection{Prosesi Tradisi Ruwatan Adat Jawa}

Upacara ruwatan yang diselenggarakan oleh masyarakat Jawa tidak terlepas dari sajian-sajian yang dimaksudkan untuk mengusir roh jahat yang berada di dalam tubuh seseorang yang di ruwat serta mantra- mantra yang diucapkan ketika melaksanakan ruwatan. Biasanya dalam ruwatan digelar wayang kulit dengan lakon Murwakala yang di dalamnya terkandung arti kehidupan yang sangat mendasar. Arti penting dalam kaitannya dengan wayang ialah masyarakat Jawa sering mengaitkan antara peristiwa yang terjadi di dalam dunia wayang dengan dunia nyata. Hakikat wayang adalah bayangan di dalam dunia nyata yang di dalamnya terdapat makhluk ciptaan Tuhan. Dalam cerita wayang juga dijelaskan beberapa syarat yang harus dipenuhi oleh anak tunggal yang diruwat agar anak tunggal tersebut tidak tertimpa musibah dan dijauhkan dari segala keburukan. Selesai acara ruwatan dan pagelaran wayang kulit, selanjutnya anak tunggal akan dimandikan dengan menggunakan macam-macam bunga setaman dan tujuh sumber air. Sebelum memandikan dalang tersebut membacakan ayat-ayat suci, do'a, dan juga mntara-mantra Jawa terlebih dahulu. Setelah dimandikan anak tunggal tersebut diharuskan membuang pakaian yang dipakainya sewaktu mandi. Membuangnya pun tidak sembarang tempat melainkan disungai yang aliran arus airnya yang cukup deras, dengan harapan semua kesialan yang telah atau bakal terjadi akan hilang dan menjauh. Setelah itu anak tunggal juga diharuskan untuk memakai pakaianpakaian yang baru sebagai penganti, dengan harapan anak tunggal tersebut telah memulai lembaran baru dalam hidupnya yang penuh berkah dan kebahagiaan yang selalu menyertainya.

Dalam masyarakat Jawa, ruwatan memiliki ketergantungan pada siapa yang akan melaksanakan ruwatan. Jika ruwatan dilakukan oleh orang yang memang memiliki kemampuan ekonomi yang memadai maka biasanya dilakukan secara besar-besaran yaitu dengan mengadakan pagelaran wayang kulit. Pada umunya ruwatan dilakukan pada siang hari dengan cara-cara tertentu, seperti selametan. Pada saat selametan juga dianjurkan untuk membuat sesaji seperti yang dibuat dari beras, pisang, kelapa. Sesaji ini sebagai wujud terima kasih kepada gusti 
sang maha pencipta. Syarat-syarat yang harus dipenuhi, yaitu

a. Nasi kuning, yang mempunyai makna yaitu mendapatkan rezeki yang berlebihan.

b. Nasi golong, yng mempunyai makna yitu agar mendapatkan rezeki yang bergantian.

c. Tumpeng, yang mempunyai makna yaitu untuk mensyukuri sebuah kenikmatan yang sudah diberikan kepadanya.

d. Nasi kabuli, menurut orang Jawa mempunyai arti bahwa jika mempunyai keinginan atau hajad agar dapat terkabulkan.

e. Jenang abang, yang terbuat dari ketan dan dikasih gula sama kelapa.

f. Bubur sengkolo, yang mempunyai makna untuk membuang atau menjauhkan kesialan.

g. Jajan pasar, yang mempunyai makna tersendiri yaitu semoga mendapatkan rezeki yang banyak dan jauh dari permasalahan.

h. Rujak legi, mempunyai arti sebagai lambang penafsirn seperti yang biasanya dibuat untuk sajian orang hamil pada saat masa mitoni atau tujuh bulan.

Selain itu, juga ada berbagai macam peralatan yang dibutuhkan dalam tradisi ruwatan anak tunggal ini yang wajib untuk dipenuhi, yaitu peralatan dapur (entong, sutil, siwur, pisau, ember, baki, kukusan, panci, dandang, sabulkan, erus) dan peralatan untuk diri sendiri (baju, kerudung, sandal, alat kosmetik, tikar, bantal, kain warna putih).

Selain itu, orang yang menyelenggarakan ruwatan ini biasanya harus melengkapi syarat-syarat yang diperlukan antara lain yaitu sajen. Sajen untuk upacara ruwatan terdiri dari 1) tuwuhan, 2) nasi golong, 3) nasi kuning, 4) nasi kabuli, 5) tumpeng, 6) jenang abang, 7) jenang sengkolo, 8) jenang grendul, 9) apem, 10) jajanan pasar, 11) ruja (pisang klutuk), 12) padi, 13) ndok Jawa (telur Jawa), 14) gedang ayu, 15) pisang raja, 16) daun kluwih, 17) daun alang-alang, 18) jambe, 19) gambir, 20) suruh, 21) kembang setaman, 22) air tujuh sumber, 23) duparatus (dupa), 24) ember, 25) cempluk (lampu minyak), 26) kendhi, 27) siwur batok, 28) kain lawon putih, 29) kain batik, 30) benang lawe, 31) kelapa, dan 32) kinang dan rokok.

\section{Kesimpulan}

Ruwatan merupakan suatu tradisi adat Jawa yang wajib untuk dilakukan. Apabila tidak dilaksanakan maka anak perempuan tunggal akan mendapatkan kesialan, musibah, dan bahaya yang akan mengancam juga mempengaruhi terhadap keutuhan rumah tangga anak tunggal tersebut.

\section{Daftar Pustaka}

Adeney, B. (2000). Etika Sosial Lintas Budaya. Yogyakarta: Pustaka Teologi dan Gandum Mas.

Fuadah, L. (2018). Tradisi Ruwatan Dalam Acara Pranikah Bagi Anak "ontanganting” Perspektif Hukum Islam. Purwokerto: Fakultas Syari'ah Institut Agama Islam Negeri Purwokerto.

Hariwijaya, M. (2005). Perkawinan Adat Jawa. Yogyakarta: Hanggar.

Koentjaraningrat. (1985). Asas Asas Ritus, Upacara dan Religi. Dalam Koentjaraningrat (Ed), Ritus Peralihan di Indonesia ( hal 11-48). Jakarta: Balai Pustaka.

Melalatoa, J. M. (1995). Ensiklopedi Suku Bangsa di Indonesia. Jakarta: CV Eka Putra.

Moleong, L, J. (2002). Metodologi Penelitian Kualitatif. Bandung: PT Remaja Rosdakarya Ofsett Bandung.

Nasution. (1992). Matode metode Penelitian Naturalistik Kualitatif. Bandung: Tarsito.

Noraini, A. (2016). Tradisi Ruwatan Bagi Anak "Ontang-anting" Sebagai Syarat Perkawinan. Yogyakarta: Fakultas Syari'ah Dan Hukum UIN. 
Soetarto. (1980). Tinjauan Asal Mula Wyang Purwa. Surakarta: PJKT.

Suyono, A. (1985). Kamus Antropologi. Jakarta: Akademika.

Zulfa, U. (2009). Tinjauan Hukum Islam Terhadap Adat Ruwatan Perkawinan Anak Tunggal Di Desa Puworejo Kecamatan Bonang Kabupaten Demak. Semarang: Fakultas Syari'ah Institut Agama Islam Negeri Walisongo. 